\title{
EVIDENCE FOR THE DOWNWARD MOVEMENT OF MATERIALS INJECTED INTO TREES
}

\author{
Terry A. Tattar and Stacy J. Tattar
}

\begin{abstract}
Movement of the xylem-mobile dyes (acid fuchsin, saffranin $O$, and gentian violet) after lower trunk or root flare injection was found to occur both upward into the xylem of stems, twigs, and leaves and downward into the xylem of woody roots, at most times of year when soil temperatures equaled or exceeded $5^{\circ} \mathrm{C}\left(40^{\circ} \mathrm{F}\right)$. Similar patterns of movement of xylem-mobile dyes were observed on the following species tested: American chestnut, black birch, eastern hemlock, eastern white pine, red maple, red oak, weeping willow, white ash, and white birch. Downward movement of dye into root systems involved all ages of xylem tissues present within a root, while upward movement was confined to the most recently formed xylem growth ring. Evidence is presented of initial downward dye movement followed by later upward movement within a 12 -hour period. Our results suggest that xylem-mobile materials injected into trees may be distributed into stem, leaf and root tissues under most growing conditions.
\end{abstract}

Key Words. Systemic movement; fertilizer.

The movement of sap from the roots to the top of tall trees has fascinated both scientists and others who wondered how a tree works. It is hypothesized that the loss of water (evaporation) from the leaves causes a tension, or "pull," on many tiny water columns within wood (Campbell et al. 1999). Because water is also cohesive, these combined forces can pull the water in a tree upward sometimes over $100 \mathrm{~m}(300$ ft) from the roots (Zimmerman 1983). This explanation for upward sap movement is known as the cohesion-tension theory and is widely accepted by tree scientists (Salisbury and Ross 1992). Because no corresponding theory has been proposed to explain the possibility of downward sap movement, it has often been concluded that sap flow occurred in the upward direction only.

However, experimental field data from those who studied sap movement in plants and vascular diseases of trees have shown evidence of downward movement for over 250 years (Banfield 1941). Many of these researchers used dyes or spore suspensions to track the downward movement of sap in trees. Banfield's studies on American elms demonstrated that both upward and downward movement occurred from injection points on the elm trees at equal speed. Extensive studies of sap movement by Greenidge (1958) using a sap mobile dye on a wide variety of trees-including American elm, balsam poplar, balsam fir, American beech, yellow birch, ironwood, sugar maple, white spruce, and white ash-supported the evidence of downward sap movement found earlier by Banfield and others.

Microinjection of the antibiotic oxytetracycline has been used to relieve symptoms of numerous bacterial diseases of trees, including bacterial leaf scorch (Kostka et al. 1988), peach X-disease (Cooley et al. 1992), and lethal yellows of cocunut palm (McCoy 1983). High populations of bacteria within the root system have often been associated with diseases caused by systemic bacteria (Sinclair et al. 1987; Cha and Tattar 1991; Blanchard and Tattar 1997 ). It has puzzled scientists how a systemic chemotherapeutant, such as oxytetracycline, could be effective if xylem movement of injected materials occurred in the upward direction only.

The objectives of this study were to determine 1) the direction of movement of injected materials in the xylem of trees using xylem-mobile dyes and 2) how time of year of injection influences dye movement.

\section{MATERIALS AND METHODS}

The trees used in these studies were growing in the Shade Tree Laboratory Nursery in Hadley, Massachusetts, and in the Cadwell Memorial Forest in Pelham, Massachusetts. Both these research facilities are part of the University of Massachusetts at Amherst. The trees ranged in size from $5 \mathrm{~cm}$ ( $2 \mathrm{in}$.) to $25 \mathrm{~cm}$ (10 in.) in stem diameter at $1.4 \mathrm{~m} \quad(4.5 \mathrm{ft})$ aboveground. The following species were injected: red maple (Acer rubrum), eastern white pine (Pinus strobus), red oak (Quercus rubra), eastern hemlock (Tsuga canadensis), white birch (Betula alba), black birch (B. lenta), 
American chestnut (Castanea dentata), white ash (Franxinus americana), and weeping willow (Salix babylonica).

Tree injection wounds were made with a batterypowered drill (800 rpm), using an $6 \mathrm{~mm}$ (11/64-in.) high-speed steel drill bit. Injection holes were made in the lower trunk and root flare areas, and hole depths were between 6 and $12 \mathrm{~mm}$ (1/4 and 1/2 in.) In one study conducted during the 1997 summer season, however, injection wounds were made at $1.4 \mathrm{~m}$ (4.5 ft) above ground to American chestnut and red oak trees. Initial experiments were conducted using Mauget microinjection capsules filled with approximately $10 \mathrm{~mL}(0.34 \mathrm{oz})$ of xylem-mobile dye solutions, pressurized to 1 atmosphere, and attached to plastic feeder tubes, which were placed into injection wounds. Later experiments used an unpressurized reservoir container filled with 25 to $50 \mathrm{~mL}$ ( 0.85 to $1.7 \mathrm{oz}$ ) of dye solution that was attached via plastic (Tygon) tubing to a feeder tube and inserted into the injection wound. The following xylem-mobile dyes at $2 \% \mathrm{w} / \mathrm{v}$ were each used during these experiments: acid fuchsin, gentian violet, and safranin $O$.

Trees were injected with the test dye solutions in late spring during leaf expansion through mid fall after leaf drop. Experiments were conducted over a 3year period from 1996 through 1998. Dye injection studies were started either from 0800 to 1000 hours, or from 1400 to 1600 hours. In most experiments, injectors were left in the tree for 24 hours. Trees were harvested immediately after injector removal. In some experiments, dyes were injected in the morning, the experiments were terminated approximately 6 hours after injection, and trees were harvested in the afternoon. In other experiments, trees were injected in the afternoon and harvested the next morning, approximately 16 hours after injection. Soil temperature was measured at $5 \mathrm{~cm}$ ( 2 in.) below ground, using a soil thermometer, at the starting time of each injection.

On most trees $10 \mathrm{~cm}$ ( 4 in.) and smaller in diameter, the woody roots were severed with a root ax and/or handsaw, and the entire tree was examined. Soil was removed from roots by washing, and the bark was peeled from the woody roots and stem. In some larger trees, the root flare was exposed by removal of soil, with only the large roots being cut with a chainsaw, approximately 20 to $50 \mathrm{~cm}$ (8 to $20 \mathrm{in}$.) from the trunk. All stem and root sections were photographed was soon as possible after the bark was removed.

Dye movement in both the upward and downward directions in the xylem was assessed by visually estimating the amount of xylem tissue stained by the injected dye after the bark was removed. In initial studies with Mauget capsules, the capsules would empty within a few hours; however, dye patterns were difficult to visualize and photograph. Once a larger dye reservoir was employed, we were able to follow patterns of dye movement throughout the test trees.

\section{RESULTS}

Our first studies were conducted in the fall during and after onset of leaf coloration and continued after leaf drop of deciduous trees. Dye patterns, regardless of species, were always bimodal-with some dye movement upward into the stem and downward into the roots from the injection sites at the root flare. Dye movement in the initial studies was approximately split between upward movement and downward movement. Later studies displayed progressively greater downward dye movement as soil temperatures lowered from approximately $15^{\circ} \mathrm{C}\left(60^{\circ} \mathrm{F}\right)$ to $5^{\circ} \mathrm{C}$ $\left(40^{\circ} \mathrm{F}\right)$. After complete defoliation, dye movement was primarily downward when experiments were terminated in early November. These dye patterns were consistent with all species studied, in both deciduous hardwoods and conifers (Figure $1^{*}$ ). In addition, the dye patterns were also similar regardless of the dye solution used. Acid fuchsin and saffranin $O$ were most easily visualized.

Studies were conducted during leaf expansion in late spring and continued into the summer when full leaf size of deciduous trees was attained. Our initial results were similar to early fall studies, with dye movement evenly split between upward and downward directions. Experiments conducted during summer were remarkably similar to those of late spring, but even with a progressive increase in upward movement, we always noted substantial downward movement (Figure 2). During moisture limiting conditions, downward movement was found to increase. Crosssections of roots revealed dye movement into several

\footnotetext{
*Figures for this article begin on page 328. Colorized versions of the figures in this manuscript can be viewed on Dr. Tattar's University of Massachusetts faculty Web site at http://www.bio.umass.edu/micro/tattar.html
} 
years of xylem tissue (Figure 3), while stem crosssections of the same trees revealed dye confined only to springwood vessels of the current growth increment (Figure 4).

In an attempt to determine the speed of downward movement or upward movement, dye resevoirs were left on trees for fewer than 24 hours. However, even when dye reservoirs were in place for only 6 hours during day experiments and 16 hours during night experiments, bimodal movement was found. We noted on several occasions that after downward movement into the roots, the injected dye would then reverse direction in the roots and progress upward on the opposite side of the stem (Figure 5).

In the study on American chestnut and red oak with injection wounds made on stems $1.4 \mathrm{~m}(4.5 \mathrm{ft})$ aboveground, most of the acid fuchsin dye moved upward into the branches and foliage. In these experiments, only small amounts of dye moved downward compared with similar trees that were injected on the same dates at the root flare.

\section{DISCUSSION}

Downward movement within xylem can be explained by the normal condition of the functioning xylem elements, which are under negative pressure or tension, and is consistent with the cohesion-tension theory of xylem movement. A break in the xylem elements, due to an injection wound, would allow movement of the injected solution in either upward or downward directions, or both, according to the forces within the xylem elements at the time of injection.

Our results agree with those of Banfield, Greenidge and others who reported downward movement of injected dyes and fungal spores in the xylem of many tree species. These recent findings, combined with those of earlier researchers, can help explain how materials injected into the sap stream at the root flare can have efficacy in the root systems of trees. This information is especially useful in explaining the control of root problems achieved using trunk injection of antibiotics, fungicides, insecticides, and micronutrients during the growing season with active leaf transpiration. For example, these findings may help explain how trunk injection can be effective in the treatment of pathogens that are primarily transmitted through the root system, such as in oak wilt (Osterbauer and French 1992; Appel 1994), as well as provide control of the systemic bacteria discussed earlier.
Osterbauer and French (1992) reported that location of injection sites on the root flare may have resulted in movement of the propiconizole into the root system because they could not detect the fungicide above a height of $3 \mathrm{~m}$ (10 ft). Although these researchers did not conduct any propiconizole assays of root tissues, our results would support their conjecture of downward movement of the injected fungicide.

Multi-year xylem sap distribution in roots would appear to explain vascular disease control beyond one growing season achieved using injectable fungicides, such as that reported by Osterbauer and French (1992) with propiconizole. Our studies found dye movement across the entire cross-section of root xylem following lower trunk injection. It appears that portions of trunk-injected materials are transported downward into the roots and are then transported upward in the sapstream in the following season or seasons. This theory could also account for the efficacy of fall-injected materials in the following spring.

\section{LITERATURE CITED}

Appel, D.A. 1994. Identification and control of oak wilt in Texas. J. Arboric. 20:250-257.

Banfield, W.M. 1941. Distribution by the sap stream of spores of three fungi that induce vascular wilt diseases of elm. J. Agric. Res. 62:637-681.

Blanchard, R.O., and T.A. Tattar. 1997. Vascular bacterial diseases. In Field and Laboratory Guide to Tree Pathology, Chap. 16. Academic Press, San Diego. 358 pp.

Campbell, N.A., J.B. Reece, and L.G Mitchell. 1999. Transport in plants. In Biology (5th ed.), Chap. 36. Benjamin/Cummings, Menlo Park, CA.

Cha, B., and T.A. Tattar. 1991. Symptom development of ash yellows and fluctuation of mycoplasma-like organism population in white ash (Fraxinus americana L.). Arboric. J. 15:323-343.

Cooley, D, T.A. Tattar, and J. Schieffer. 1992. Treatment of $\mathrm{X}$-disease using oxytetracycline microinjection capsules. HortScience 27:235-237.

Greenidge, K.N.H. 1958. Rates and patterns of moisture movement in trees, p 1941. In Thimann, K.V. (ed.). The Physiology of Trees. Ronald Press, New York, NY. $678 \mathrm{pp}$.

Kostka, S., T.A. Tattar, and J.L. Sherald. 1985. Suppression of bacterial leaf scorch symptoms through oxytetracycline microinjection. J. Arboric. 11:54-60.

McCoy, R.E. (Ed.). 1983. Lethal yellowing of palms. Institute of Food and Aric. Sci., Univ. Florida. Bulletin $\# 834,100$ pp. 
Osterbauer, N.K., and D.W. French. 1992. Propiconazole as a treatment for oak wilt in Quercus rubra and $\mathcal{Q}$. ellipsoidalis. J. Arboric. 18:221-226.

Salisbury, F.B., and C.W. Ross. 1992. Plan Physiology (4th ed.). Wadsworth Pub. Co., Belmont, CA.

Sinclair, W.A., H.H. Lyons, and W.T. Johnson. 1987. Diseases of Trees and Shrubs. Cornell University Press, Ithaca, NY.

Zimmerman, M.H. 1983. Xylem Structure and the Ascent of Sap. Springer-Verlag, New York, NY.

Acknowledgments. The authors wish to thank Andrew Wier for his invaluable technical assistance with the figures and Dr. Ann Lewis for her critical review of the manuscript. Support for this research project was provided by the Massachusetts Agricultural Experiment Station Project NE-140 as contribution \#3243.

\section{Department of Microbiology \\ Shade Tree Laboratory \\ University of Massachusetts \\ Amherst, MA 01003}

\section{Corresponding author: Terry A. Tattar}

Résumé. On a découvert que le mouvement des colorants mobiles du xylème - acide fuchsine, safran $O$ et bleu de méthylène -, après leur injection dans la partie inférieure du tronc ou le pied de l'arbre, se produit à la fois vers le haut dans le xylème des branches, des tiges et des feuilles et vers le bas dans le xylème des racines ligneuses, et ce pratiquement toute l'année lorsque la température du sol est égale ou supérieure à $5^{\circ} \mathrm{C}$. Des patrons similaires de mouvement dans le xylème ont été observés sur l'ensemble des espèces suivantes qui ont été testées: châtaignier d'Amérique, bouleau gris, pruche du Canada, pin blanc de l'Est, érable rouge, chêne rouge, saule pleureur, frêne d'Amérique et bouleau à papier. Le mouvement vers le bas des colorants vers le système racinaire impliquait tous les tissus de xylème présents dans la racine alors que le mouvement vers le haut était confiné au xylème de l'anneau de croissance le plus récent. La preuve du mouvement initial vers le bas du colorant suivi par après de son mouvement vers le haut à l'intérieur d'une période de 12 heures est présentée. Nos résultats suggèrent que les composés injectés dans les arbres peuvent être distribués dans les branches, les feuilles et les tissus racinaires sous la plupart des conditions de croissance.

Zusammenfassung. Die Bewegungen von xylemmobilen Färbemitteln, wie Fuchsin, Saffranin $O$ und Veilchenviolett nach einer Injektion von unteren Stammteilen findet in beide Richtung in das Xylem der Äste und Zweige und in das Xylem der Wurzeln statt und zwar zu allen Jahreszeiten, wenn die Bodentemperatur auf oder über $5 \mathrm{Grad} C$ steigt. Bei allen folgenden Arten wurden ähnliche Verteilungsmuster im Xylem gefunden: Amerikanische Kastanie, Schwarzbirke, Tsuga, Weißkiefer, Rotahorn, Silberweide, Weißesche und Weißbirke. Die Abwärtsbewegung des Färbemittels in das Wurzelsystem durchzog alle xylemhaltigen Gewebe, während bei der Aufwärtsbewegung nur die kürzlich gebildeten Wachstumsringe erreicht wurden. Hier wurden Beweise gefunden für eine initiale Abwärtsbewegung des Mittels, später gefolgt von einer Aufwärtsbewegung innerhalb einer 12stündigen Periode. Unsere Ergebnisse deuten darauf hin, daß eine Injektion von Wirkstoffen, die in Stamm, Blăttern und Wurzeln verteilt werden soll, am besten unter Wachstumsbedingungen appliziert werden.

Resumen. Se encontró que el movimiento de tinturas móviles del xilema, ácido fúsico, O safranín y violeta de genciana, después de inyecciones en la porción baja de la corona de la raiz, ocurre tanto hacia arriba como dentro del xilema de los troncos, brotes y hojas y hacia abajo dentro del xilema de las raíces leñosas, la mayor parte del año, cuando las temperaturas del suelo igualaron o excedieron 40F (5C). Patrones similares de movimiento del xilema fueron observados en todas las siguientes especies probadas: Castaño americano, Abedul negro, Abeto del Canadá, Pino blanco del Canadá, Arce de Virginia, Encino de Virginia, Sauce llorón, Fresno blanco Americano y Abedul Americano. El movimiento descendente del tinte dentro de los sistemas de raíces envolvió todos los tejidos del xilema presentes dentro de una raíz mientras el movimiento ascendente del xilema estuvo confinado en la mayoría de los anillos recientemente formados. Se presenta evidencia de un movimiento inicial descendente del tinte, seguido por un movimiento posterior ascendente en un período de 12 horas. Nuestros resultados sugieren que los materiales inyectados dentro de los árboles pueden ser distribuidos dentro del tronco, hojas y tejidos de las raíces, bajo la mayoría de las condiciones de crecimiento. 


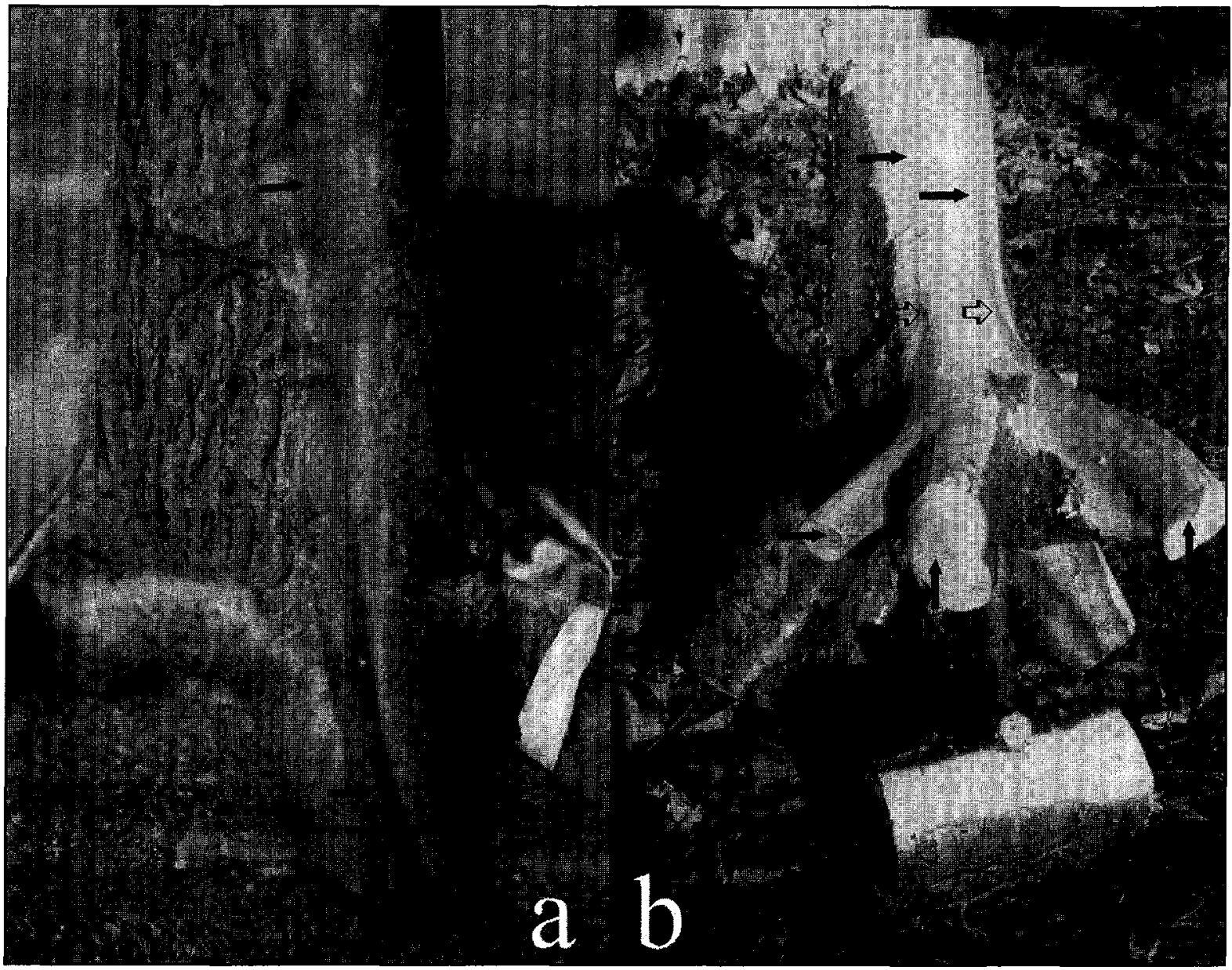

Figure 1. Downward movement of $2 \%$ acid fuchsin dye into roots of eastern hemlock (a) and yellow birch (b) 24 hours after trunk injection in October. Bark has been removed above and below injection sites. Solid arrows indicate dye position, and hollow arrows indicate site of injection wounds. 


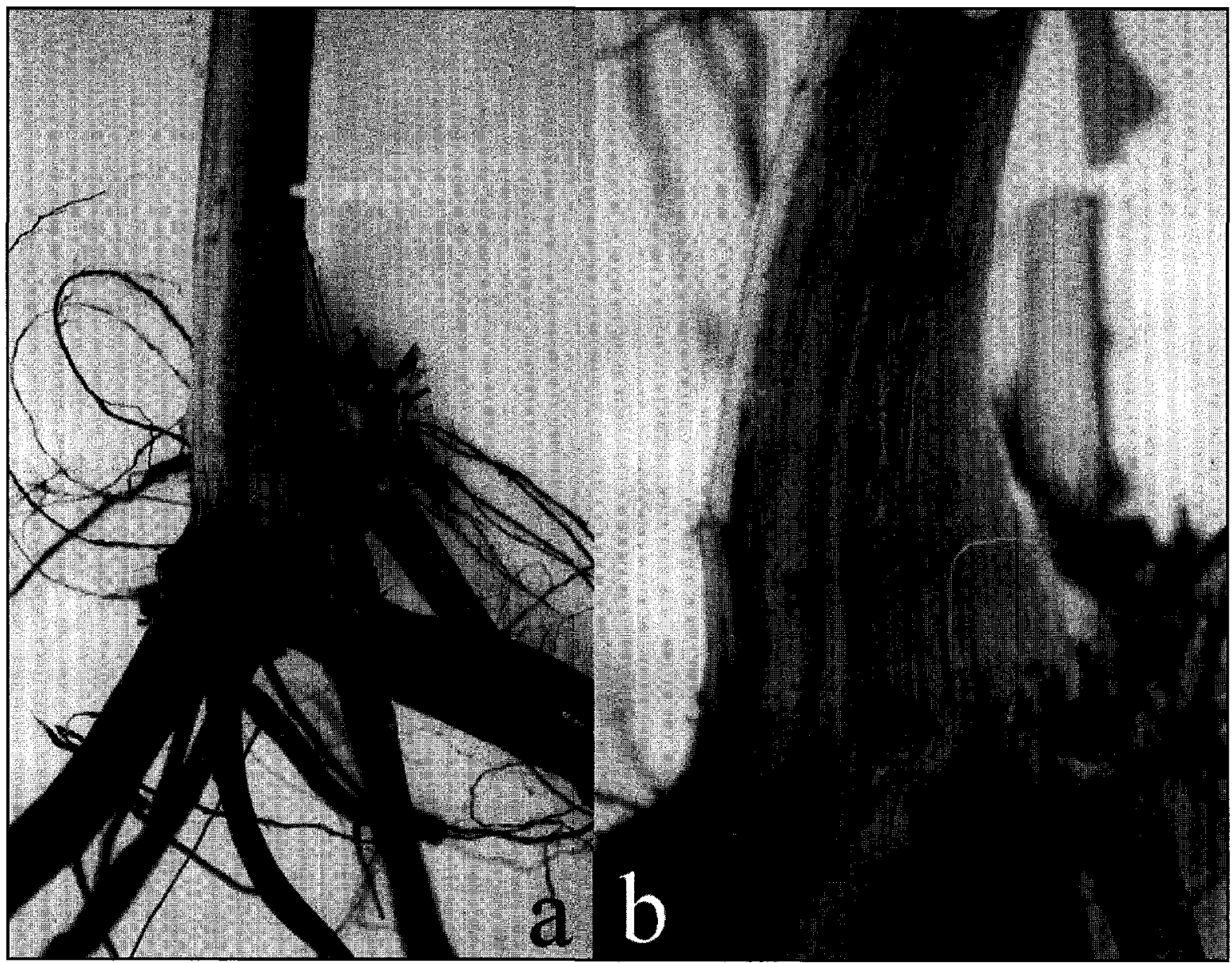

Figure 2. Downward movement of $2 \%$ acid fuchsin dye 24 hours following trunk injection of an American chestnut in July (a). Close-up, white plastic feeder tube indicates position of injection wound (b). 


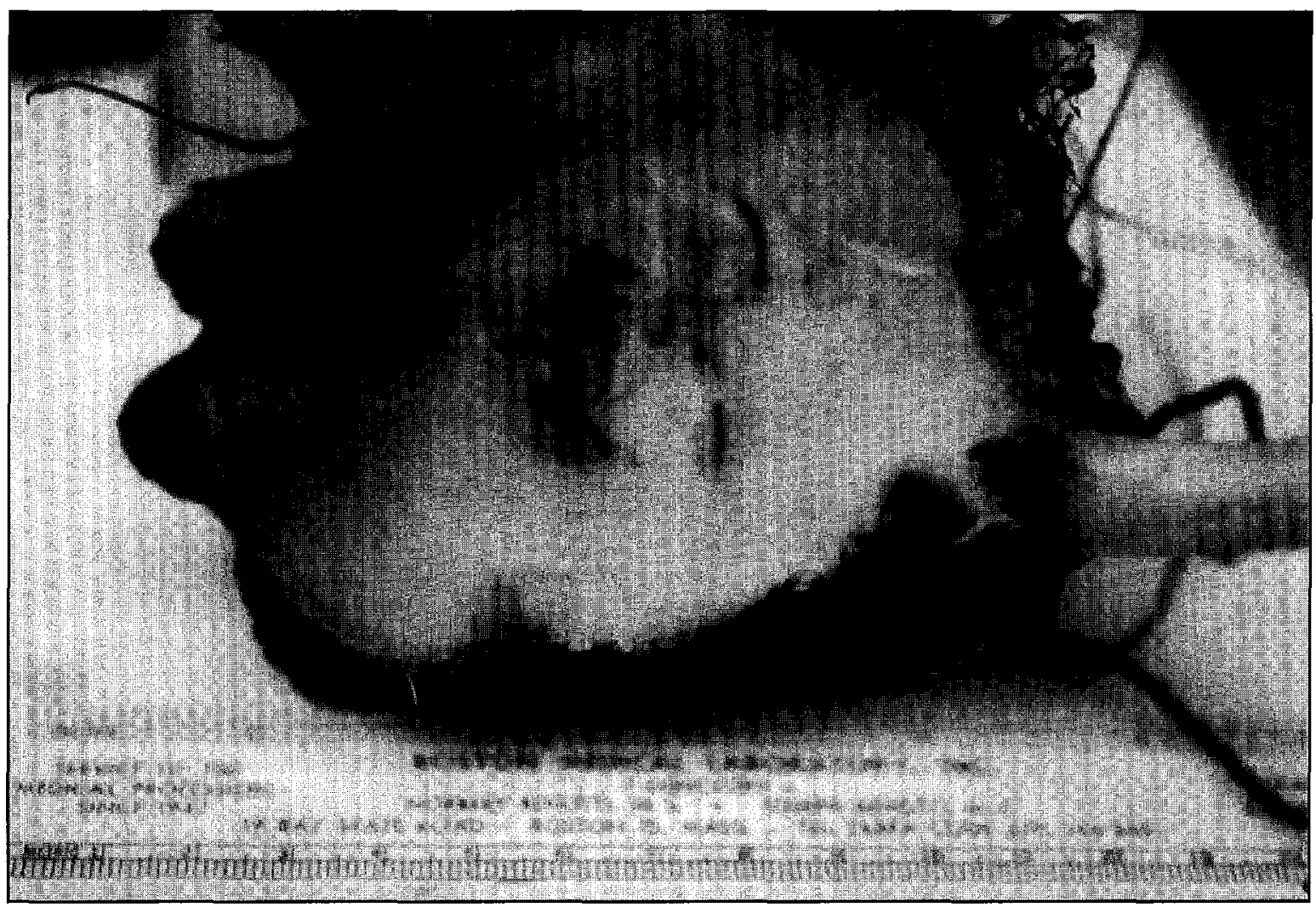

Figure 3. Cross-section of buttress of American chestnut 24 hours after trunk injection of $2 \%$ acid fuchsin dye in July. Note inward movement of dye across several years of xylem tissue.

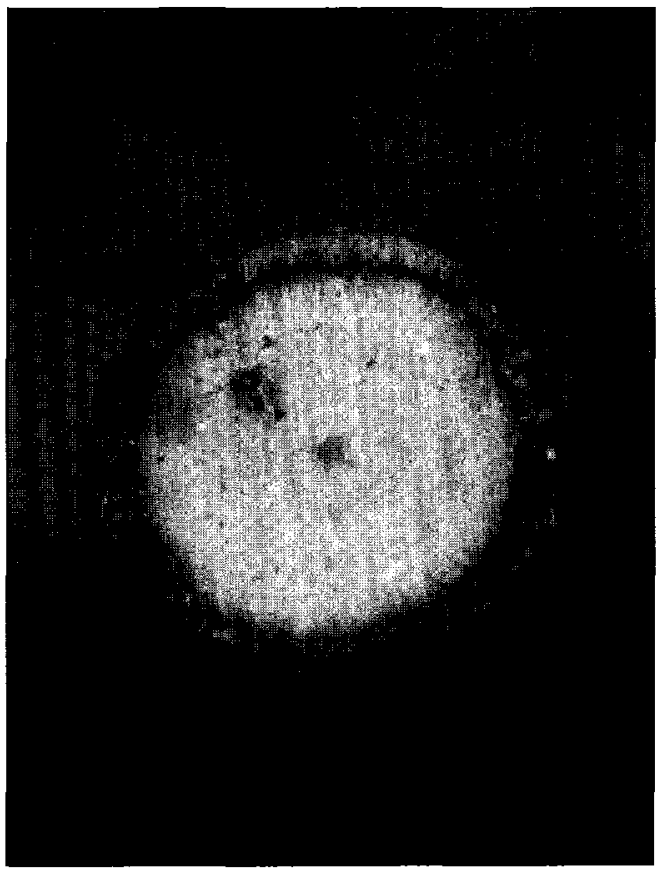

Figure 4. Cross-section of American chestnut stem at 90 $\mathrm{cm}(3 \mathrm{ft})$ above ground 24 hours following trunk injection of $2 \%$ acid fuchsin dye in July. Note that dye is confined to large springwood vessels in the current year of xylem. 


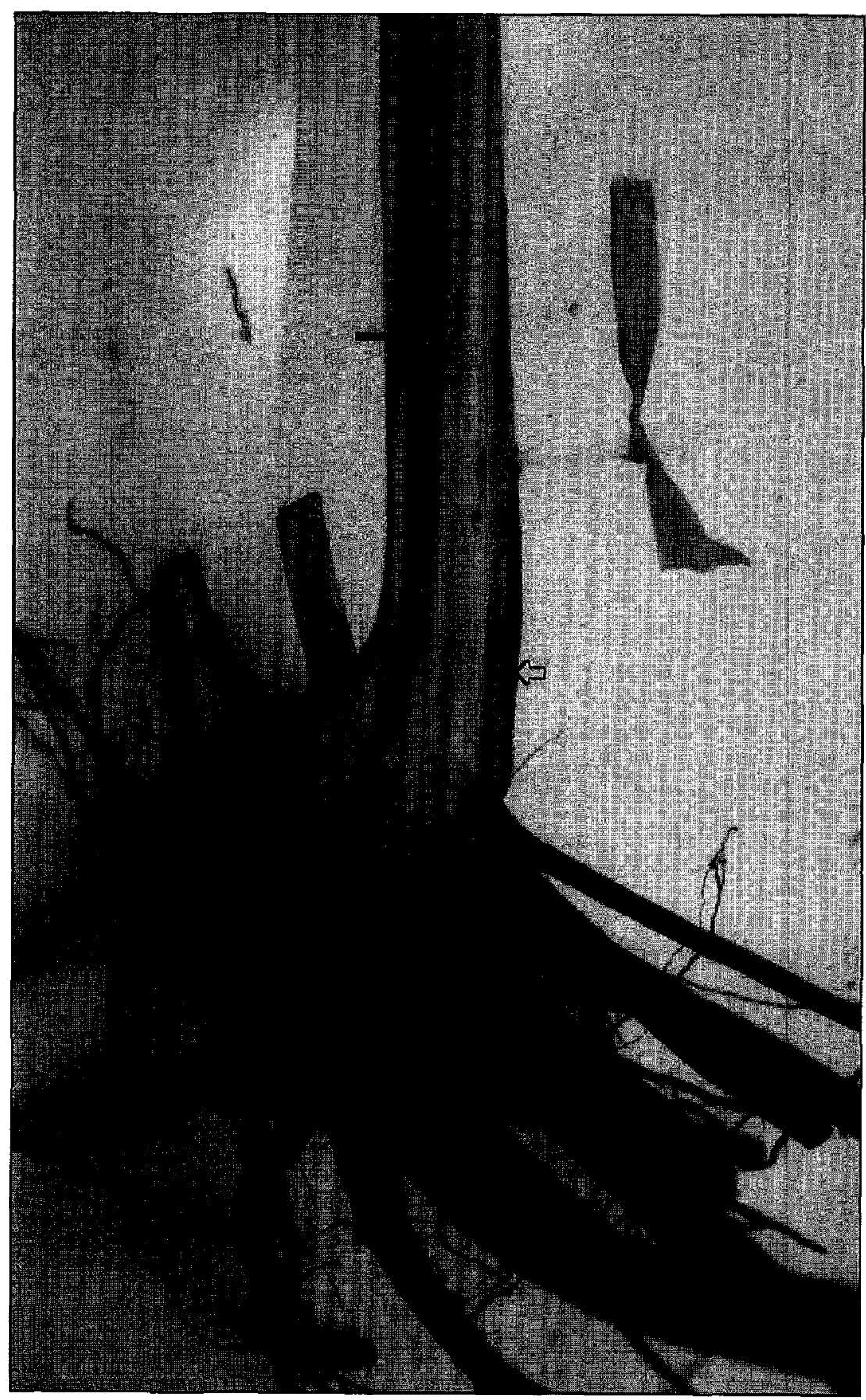

Figure 5. Upward movement of $2 \%$ acid fuchsin dye (solid arrows) after initial downward dye movement from an injection wound on the opposite side of the trunk on an American chestnut in July. Note position of plastic feeder tube with flag attached (hollow arrow) indicating postion of injection wound. 